\title{
SHRUB ENCROACHMENT IN A WOODED-STEPPE MOSAIC: COMBINING GIS METHODS WITH LANDSCAPE HISTORICAL ANALYSIS
}

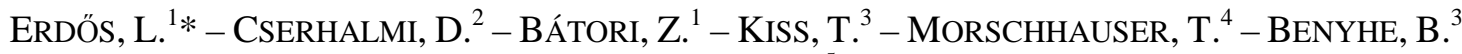 \\ - DÉNES, A. ${ }^{5}$ \\ ${ }^{1}$ University of Szeged, Department of Ecology \\ 6726 Szeged, Közép fasor 52., Hungary \\ (phone: +36-62-546-951; fax: +36-62-546-949) \\ ${ }^{2}$ Szent István University, Department of Botany \\ 1077 Budapest, Rottenbiller utca 50., Hungary \\ (phone: +36-1-478-4235; fax: +36-1-478-4238) \\ ${ }^{3}$ University of Szeged, Department of Physical Geography and Geoinformatics \\ 6722 Szeged, Egyetem utca 2-6., Hungary \\ (phone: +36-62-544-545; fax: +36-62-544-158) \\ ${ }^{4}$ University of Pécs, Department of Plant Taxonomy and Geobotany \\ 7624 Pécs, Ifjúság útja 6., Hungary \\ (phone: +36-72-503-600; fax: +36-72501-520) \\ ${ }^{5}$ Janus Pannonius Museum, Department of Natural History \\ 7621 Pécs, Szabadság utca 2., Hungary \\ (phone: +36-72-213-419; fax: +36-72-514-040) \\ *Corresponding author \\ e-mail: Erdos-Laszlo@bio.u-szeged.hu \\ (Received $18^{\text {th }}$ December 2012; accepted $2^{\text {nd }}$ September 2013)
}

\begin{abstract}
Shrub encroachment at the expense of grasslands is a world-wide phenomenon, which has considerable nature conservation consequences. On the southern slope of Mt Szársomlyó, one of Hungary's most unique nature reserves, shrubforest cover has been rapidly increasing in the past few decades. Our aim was to quantify this process and to give a comprehensive analysis of the landscape history of the area. Moreover, we compared Mt Szársomlyó to two nearby and similar mountains with a slightly different land-use history. It is almost certain that both shrubforests and grasslands were present on Mt Szársomlyó before human influence, although their original proportion is unknown. Southern slope was used as a pasture for centuries, maybe even for millennia. After grazing had come to an end during the 1970's, shrubforests began to expand rapidly: their cover increased from $9.83 \%$ in 1964 to $21.7 \%$ in 2005. In the case of the other two mountains, where grazing stopped earlier, forest cover is considerably higher than on Mt Szársomlyó, but this is partly due to the afforestation. It can be concluded that grazing of south-exposed rock swards should be regarded as a traditional land-use in the region. Further studies are needed to support nature conservation decisions.
\end{abstract}

Keywords: land-use, grazing, Mt Szársomlyó, image classification, aerial photo

\section{Introduction}

Conversion of grasslands to shrublands or forests has been documented in several environments in Africa (e.g. Prins and van der Jeugd, 1993), South America (e.g. Silva et al., 2001), North America (e.g. Burkhardt and Tisdale, 1976), Australia (e.g. Brook 
and Bowman, 2006) and Europe (e.g. Roura-Pascual et al., 2005). Since the process often entails a decrease in biodiversity, it poses serious problems for nature conservation (cf. Knapp et al., 2008; Bond and Parr, 2010). Moreover, shrub- and woodland expansion alters basic ecosystem processes, thus resulting in global consequences concerning climate and biogeochemical cycles (Schlesinger et al., 1990; Briggs et al., 2005; Knapp et al., 2008).

Possible causes of shrub encroachment include altered grazing or browsing pressure, reduced fire regime, climate change, atmospheric $\mathrm{CO}_{2}$ enrichment and nitrogen deposition (e.g. Prins and van der Jeugd, 1993; Archer et al., 1995; Köchy and Wilson, 2001; Briggs et al., 2005; Brook and Bowman, 2006). Identification of the real driving factors is a hard task (Wigley et al., 2010). Relative importance of different drivers varies among regions (Knapp et al., 2008). Moreover, these factors do not operate separately, but they often interact (e.g. the effects of grazing and fire: Moleele and Perkins, 1998; Roques et al., 2001; Ónodi et al., 2008; effects of fire and $\mathrm{CO}_{2}$ : Bond et al., 2003). Besides, differentiating between cause and effect is often problematic (cf. Bradshaw et al., 2003).

There is increasing evidence that shrub encroachment is - at least partly - a result of overgrazing in some ecosystems. It seems that in several African and American landscapes, reduced grass biomass through increased grazing diminishes available fuel for fires. Reduction or cessation of fires favours fire-resistant shrubs (Burkhardt and Tisdale, 1976; van Auken, 2000; Roques et al., 2001). Also, trampling of large ungulates reduces competition of grasses on shrubs and trees, and grazing animals contribute to the seed distribution of certain shrub species (Archer et al., 1988; van Auken, 2000; Laliberte et al., 2004).

Several types of xeric grasslands tend to turn into shrublands or forests in Eastern Europe (cf. Cremene et al., 2005; Molnár et al., 2008), which is considered one of the major landscape changes occurring in the region (Sallay et al., 2012). However, causes and mechanisms differ fundamentally from those in most African and American grasslands. Generally, it is supposed that expansion of woody vegetation is not the result of overgrazing, but the result of undergrazing (e.g. Somodi et al., 2004; Centeri et al., 2009; Sărăţeanu and Moisuc, 2011; Kiss et al., 2011).

Mt Szársomlyó (South Hungary) is a strictly protected nature reserve, south-facing slope of which is covered by a mosaic of xeric shrubforests and grasslands (Erdös et al., 2012). The cover of shrubforest patches has been rapidly increasing in the last few decades. Although this phenomenon may have important implications for nature conservation, the process has not been quantified yet, and the evaluation of its possible causes and probable consequences is also lacking. This paper presents the analysis of the change in shrubforest cover between 1964 and 2005, using aerial photographs. It also reveals the landscape history of the area, using botanical data, historical documents, old travel reports and maps, interviews with locals and our own observations. Special attention is paid to the possible link between land-use change and shrub encroachment. Finally, Mt Szársomlyó is compared to two nearby and similar mountains, where grazing had ceased earlier. 


\section{Materials and methods}

\section{Study area}

Our study area was Mt Szársomlyó (442 m asl), part of the Villány Mts (southern Hungary). Mean annual temperature is $10-10.5{ }^{\circ} \mathrm{C}$ (Fodor, 1977), mean annual precipitation varies between $670 \mathrm{~mm}$ and $690 \mathrm{~mm}$ (Ambrózy and Kozma, 1990). The bedrock consists of limestone (Marosi and Szilárd, 1981). Typical soil of the northern slope is brown forest soil, whereas that of the southern one is rendzina (Lovász, 1977). The soil is quite thin, thus the surface exhibits an extensive karren field. Between the karstic limestone ridges, grikes (solution fissures formed by the karstification of limestone) have developed, where soil is thicker and soil-moisture content is higher.

Mt Szársomlyó is extremely diverse, harbouring several endemic and relict plant species, some of which do not occur elsewhere is the region (cf. Dénes, 2000). Also, it supports a very rich fauna, with several threatened species. Most characteristic plant communities of the southern slope are the shrubforest Inulo spiraeifoliae-Quercetum pubescentis and the rock sward Sedo sopianae-Festucetum dalmaticae, forming a mosaic-like complex (Erdős et al., 2012) (Fig. 1). Shrubforests appear in small patches, diameter of which is usually 10-20 m. Canopy height is 2-5 m, the dominant species are Quercus pubescens and Fraxinus ornus. The shrub layer consists of Crataegus monogyna, Euonymus verrucosus, Ligustrum vulgare and Ruscus aculeatus. In the herb layer, Asplenium javorkeanum, Dictamnus albus, Geum urbanum, Iris variegata, Polygonatum odoratum are the most frequent (Dénes, 1995). Rock swards of Mt Szársomlyó are open grasslands, where vegetation cover is $40-70 \%$, the remaining area is partly bare soil, partly rock. Height of the grassland is not more than $50 \mathrm{~cm}$, dominated by grass species, among others Botriochloa ischaemum, Cleistogenes serotina, Festuca dalmatica, Melica ciliata, and Stipa spp. Other frequent plants include Artemisia alba, Colchicum hungaricum, Convolvulus cantabrica, Dianthus giganteiformis, Medicago orbicularis, Thymus spp. and Trigonella gladiata. Ferns, mosses and lichens are also considerable (Dénes, 1998). Mt Szársomlyó is protected since 1944 (Reuter, 1976).

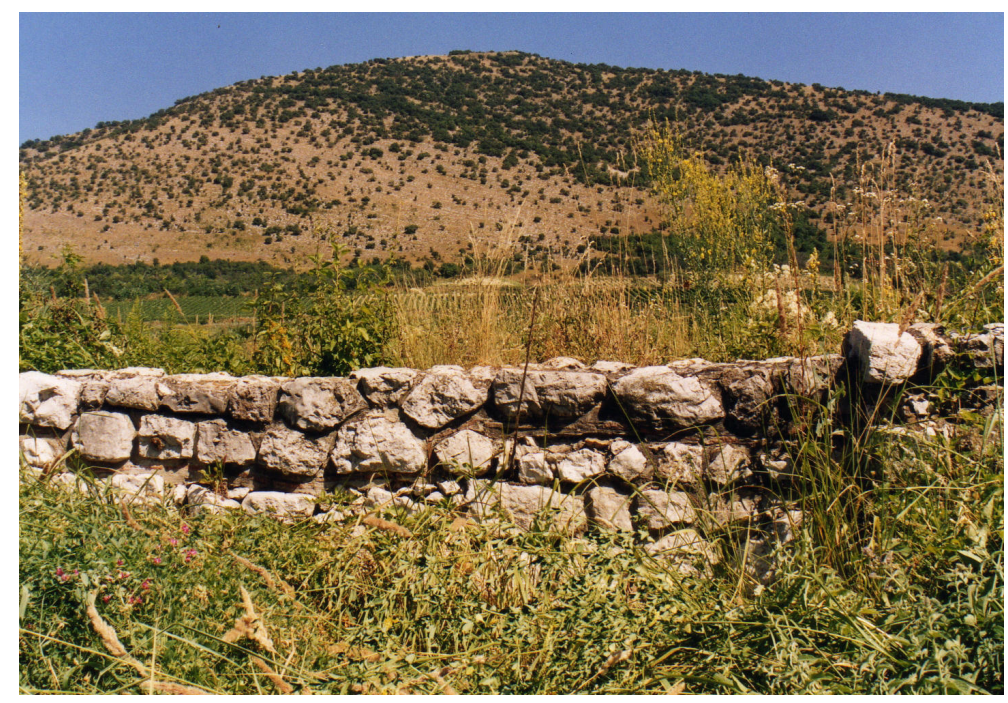

Figure 1. Southern slope of Mt Szársomlyó, with a xeric vegetation mosaic. In the foreground, ruins of a Roman settlement 


\section{Aerial photographs, image interpretation, accuracy assessment}

Several digital change detection methods are available for monitoring ecosystem changes (Coppin et al., 2004). Even though object based methods (such as image segmentation) play a greater role in vegetation science, simple pixel based classification methods still have a considerable importance. For panchromatic aerial photos, these latter methods can only be used when a relatively small number of categories are separated (Cserhalmi and Kristóf, 2007). At the same time, it is possible to separate habitats with different texture, e.g. trees vs. shrubs (Kadmon and Harari-Kremer, 1999), or single trees vs. open areas (Lahav-Ginott et al., 2001).

Altogether, three images covering a 40-year period were available, with image acquisitions in the following years: 1964, 1984, and 2005. The true colour image of 2005 was supplied by the Institute of Geodesy, Cartography and Remote Sensing (FÖMI) with a ground resolution of $0,6 \mathrm{~m} / \mathrm{px}$. The other two images were only panchromatic photos supplied by the Ministry of Defense Mapping Company with 0,3$04 \mathrm{~m} / \mathrm{px}$. Our main goal was to measure the distribution of forested and non-forested areas, thus, digital terrain model was unnecessary. For panchromatic photos, contrast enchantment was used.

For non-supervised classification, ERDAS Imagine 8.4 was used. As pixel values range widely even for a homogenous tree dominated area, using only two classes for the classification leads to incorrect result. For more accurate result different number of classes was tested and at last six classes seemed to be optimal. The result map was postprocessed with ArcView 3.1 where classes were merged, and only two categories remained.

In the analysis, only the shrubforests and open rock swards were considered, covering almost the whole natural area of the southern slope. The closed steppe at the foot of the mountain, as well as man-made landscape elements (vineyards, stonequarry) were excluded from the classification.

Congalton and Green (1999) describe several ways of accuracy assessment. The two major methods measure thematic and positional accuracy. The error matrix is developed to assess the accuracy of thematic maps (Stehman and Czapwleski, 1998). For the other method, the coordinates of larger scaled maps or GPS data are required. In this case, at least 20 samples are suggested, but more than 30 samples per class are preferred.

For accuracy assessment, reference data could only be collected for the image of 2005 as there was no such vegetation map for the previous periods. If the classification of this image is considered accurate, the method can be applied for the historical images as well. Random GPS control points were collected at the study site: 31 points for the grassland patches and 33 for the shrubforest patches. Control points were overlapped on the classification map and the agreement was calculated.

\section{Landscape history}

Landscape historical researches can improve our knowledge about the origin and dynamics of vegetation, as well as about the effects of land-use (Molnár and Biró, 2010). In landscape historical analyses, several direct and indirect sources can be used, such as old maps, historic documents, knowledge of local people and botanical data (Molnár and Biró, 2010).

The history of Mt Szársomlyó was reconstructed using the following data sources: botanical data (Bartosságh, 1843; Dénes, 2000; Zólyomi, 2007; Erdős et al., 2011); 
publications on local history (Fülep and Sz. Burger, 1979; Lajber, 2000; Szita, 2002); usage and etymology of the local geographical names (Lehmann, 1975, 1979; Pesti, 1982; Györffy, 1987; Kiss, 1997; Sándor, 2011); origin of a local folk legend (Haas, 1845; Várady, 1896; Vargha et al., 1991; Pesti, 2002); travel reports, diaries (Marsigli, 1699, cited by Szita, 2002; Kitaibel, 1799 and 1808, cited by Horvát, 1942; Elsner, 1845, cited by Lajber, 1995; Patkovics, 1845, cited by Szita, 1986; Nendtvich, 1873, cited by Simonkai, 1876); documents from the Baranya County Archives; historic maps from 1844, 1862 and 1864; interviews with local inhabitants who have been living here for several decades; our own observations from the 1980's onwards.

\section{Comparison with two similar mountains}

For comparison, two montains were chosen: Mt Tenkes (appr. $13 \mathrm{~km}$ to the west) and Mt Tubes (appr. $30 \mathrm{~km}$ to the northwest). The choice seemed reasonable because both mountains are similar to Mt Szársomlyó (cf. Erdős et al., 2012, 2013): bedrock is limestone and dolomite (Mt Tenkes) or limestone (Mt Tubes); they have steep southexposed slopes; these slopes support grassland-forest mosaics; there are settlements near the southern mountain foots; the southern slopes had been grazed for a long time. It was supposed, however, that grazing did not cease at the same time in the case of the three mountains. To identify when grazing was abandoned, following documents were checked. In the case of Mt Tenkes: Postcard Collection of Károly Borsy in the Baranya County Archives, Postcard Collection of the Department of History of the Janus Pannonius Museum and written documents of the Baranya County Archives. In the case of Mt Tubes: Description of the First Military Survey in 1783-84 (HM Hadtörténeti Intézet és Múzeum Térképtára), Ágh (1894), Horvát (1944). Using aerial photographs from the year 2005 (supplied by the Institute of Geodesy, Cartography and Remote Sensing), we wanted to find out if there is a greater forest-cover where grazing ceased earlier. During the classification, we applied the same methods as described above.

\section{Results}

\section{Quantification of the shrub encroachment}

Considering the rock sward patches, all 31 GPS control points agreed with the classification map (100\% accuracy). As for the shrubforest patches, 29 points matched with the classification map (87.87\% accuracy). Of the four incorrect points, two were rather small habitats (smaller than $3 \mathrm{~m}$ in diameter). Considering all control points for the two categories, overall accuracy was $93.75 \%$, as 60 reference GPS points agreed with the classified data. Although we cannot use reference data for the historical aerial photo, the high accuracy of the 2005 photo suggests high reliability for the classification of the 1964 image.

Our results show that proportion of the area occupied by shrubforests was $9.83 \%$ in 1964. This increased to $21.7 \%$ by 2005 (Fig. 2). Classification of the 1984 aerial photo proved rather problematic; proportion of shrubforests was between $11.07 \%$ and $19.82 \%$. The pattern of the shrubforest patches suggests that the spread of the wood vegetation follows the grikes and gullies, where soil conditions are more favourable for seedlings. 

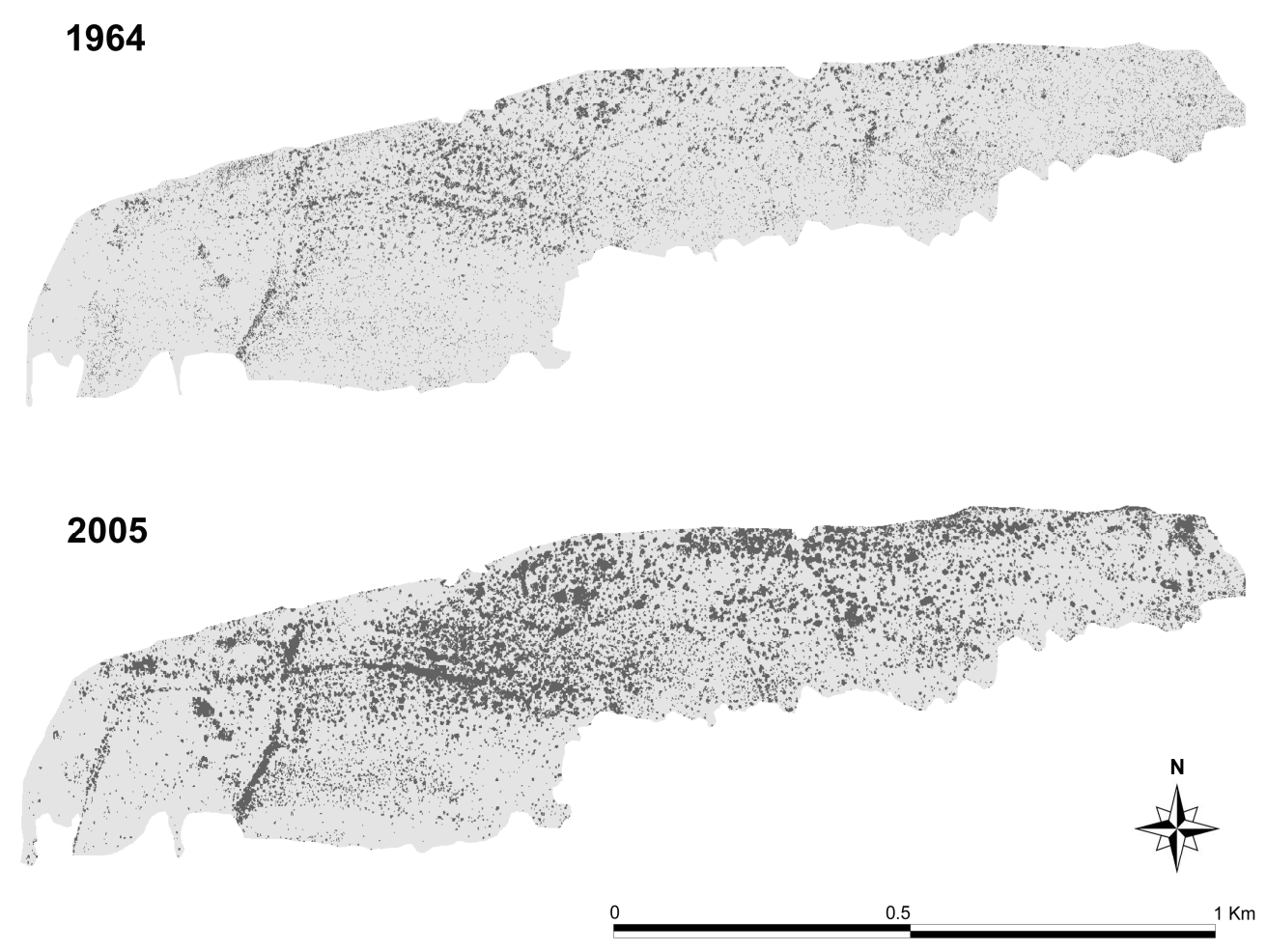

Figure 2. Changes in the proportion of shrubforest-rock sward cover on the southern slope of Mt Szársomlyó between 1964 and 2005. Black pixels indicate shrubforests, grey pixels represent grasslands

\section{Landscape history of the southern slope and its potential connection with vegetation change}

Natural vegetation (i. e. vegetation before intensive human impacts) on the southern slope of Mt Szársomlyó must have consisted mainly of Illyrian type hairy oak forests, shrubforests and rock swards (Zólyomi, 2007). This is supported by an analysis of shrubforests and rock swards in the Villány Mts: several plants were identified that were restricted either to forest or to grassland interiors (Erdös et al., 2011). Since these species can exist only in one of the two habitat types, it can reasonably be assumed that both shrubforests and treeless grasslands must have existed long before human intervention. Moreover, both components of the mosaic harbour an extremely high diversity, including a number of rare plants, some of which cannot be found elsewhere in the region and have weak dispersal capabilities (cf. Dénes, 2000). Thus, although the proportion of forests and grasslands was most probably different from what we see today, the last natural vegetation before intensive human impact certainly consisted of both shrubforests and rock swards on the south-exposed slope.

According to archeological finds, the southern foot of Mt Szársomlyó was inhabited as early as the $11^{\text {th }}$ century B.C. (Szita, 2002). Later, in the first century A.D., a small Roman settlement had formed, as indicated by ruins of houses, a church, public baths with floor-heating, a cemetery and other finds, such as mosaics and sculptures (Fülep and Sz. Burger, 1979). The first vineyards were probably established by Roman inhabitants (Lajber, 2000), presumably in the place of former xeric oak forests (Lehmann, 1979). It is also assumed that Romans opened the first stone-quarry in the 
area (Szita, 2002). Later, other ethnic groups lived near Mt Szársomlyó, until Hungarians settled down in the $11^{\text {th }}$ century A.D. All nations mentioned above bred livestock, so they certainly used pastures. Lowlands south of Mt Szársomlyó were marshy till the $19^{\text {th }}$ century, partly as a consequence of the relative proximity of River Dráva. Patkovics wrote in 1845 (cited in Szita, 1986), that marshes on the southern hillfoots of the Villány Mts dried out only rarely. Moreover, most grasslands were too wet for grazing even during the $20^{\text {th }}$ century, as indicated by our interviews. Thus, southern slopes of the Villány Mts provided the only considerable areas for grazing. Among them, southern side of Mt Szársomlyó must have been one of the most important pastures, since it was in the immediate proximity of the settlements mentioned above.

When studying documents from the $13^{\text {th }}$ and $14^{\text {th }}$ centuries, Mt Szársomlyó was mentioned in the following dates: 1249, 1287, 1289, 1291, 1296, 1319, 1340 (Györffy, 1987). In old Hungarian, the word 'Szársomlyó' means 'treeless mountain' or 'bushless mountain' (Kiss, 1997). This suggests that at least the southern slopes were dominated by grasslands (Lehmann, 1975, 1979). According to a less likely explanation (Sándor, 2011), the word 'Szársomlyó' originally meant 'a white place with lots of cornel'. White probably referred to the light-grey karren field, and cornel to the abundance of Cornus mas. Also, the southern foot of the mountain is called 'kopár', meaning 'sparsely vegetated' (Kiss, 1997). However, we have no data as for when this latter local name appeared first.

There are very few data relating to the following centuries. What we do know is that the village south of Mt Szársomlyó became deserted by 1687, due to war devastations (Szita, 2002). From this, it could be supposed that grazing diminished or ceased completely, resulting in shrub or tree encroachment. However, the Italian geographer Marsigli mentioned in his diary in 1699 (cited in Szita, 2002) that the northern slope of Mt Szársomlyó is covered by forests - which probably indicates that the southern side was not forested. The great Hungarian botanist, Kitaibel wrote in 1799 (cited in Horvát, 1942) that the Villány Mts are mostly treeless, while the northern side of Mt Szársomlyó is occupied by forests. Kitaibel gave a more detailed description in 1808 (cited in Horvát, 1942), writing that southern slope of Mt Szársomlyó is bare, full of rocks and stones, with only a few shrubs. Similarly, Elsner described Mt Szársomlyó in 1845 (cited in Lajber, 1995) as looking like a plough-land from the distance.

According to a popular and wide-spread legend, the devil himself ploughed up the southern slope of Mt Szársomlyó, and that is why it is so bare today (Haas, 1845; Várady, 1896; see also Vargha et al., 1991; Pesti, 2002). The legend was first written down in the $19^{\text {th }}$ century, but it certainly originated from earlier times. Existence of this legend can only be explained if more or less continuous bareness of the southern slope is presumed.

Mt Szársomlyó was one of the first localities in Hungary, where the invasive alien tree Ailanthus altissima was planted (Bartosságh, 1843). The species became established, and it spread on the southern slope. However, most individuals die spontaneously in a young age. Thus, A. altissima does not contribute significantly to shrub encroachment on Mt Szársomlyó at the moment.

The first reliable data concerning land-use originate from the $19^{\text {th }}$ century. According to the maps from 1844, 1862 and 1864 (Maps 1-3), the total area of the southern mountain side was used as a pasture. Nendtvich also noted in 1873 (cited by Simonkai, 1876) that the slope is continuously grazed. 
We have more detailed information from the $20^{\text {th }}$ century, based on the interviews and archive documents. The southern slope of Mt Szársomlyó (and also a part of the northern slope) was the main pasture of the village Nagyharsány throughout the $20^{\text {th }}$ century. Hundreds, maybe thousands of sheep grazed here, accompanied by a few tens of goats and some donkeys. Grazing season lasted from spring till autumn. Goats were grazing partly with the sheep herds, partly on a separate area designated for goats (BML IV/418.b/1). It was observed by the local grazing association in 1930 that goats ate off every shrub and contributed to increased erosion (BML IV/418.b/1). Cattles and pigs were allowed to graze on the foot of the mountain only. As pasture management, trees and shrubs were regularly cut (wood was sold), and the pasture was burnt (BML IV/418.b/2; BML IV/418.b/3). (At present, fires are suppressed, but accidental fires occurred in March 2000 and June 2000. The observations after the fire events suggested that hardly any full-grown shrubs or trees had been severely affected. However, the possible effects of recurring fires on the seedlings of woody species are unknown.) Besides the pasture function of the southern slope, local inhabitants also collected firewood here. Moreover, documents from 1933 show that it also served as a hunting-field, where game was fed during winter seasons (BML IV/418.b/2; BML IV/418.b/4).

Around the middle of the $20^{\text {th }}$ century, number of grazing animals started to decrease, and grazing ceased almost completely by the 1970's. Grazing continued with very few animals, and was restricted to the foot of the mountain, thus it is right to regard the 1970's as the end of the grazing for most of the shrubforest-rock sward mosaic. The last small grazing sheep herd was seen in 1987. Since then, native herbivores such as roe-deer, hares and wild-boars have occasionally been encountered on the southern slope, but their effect on the woody vegetation seems to be minimal.

During the First World War, trenches were established on the eastern part of the southern slope, where the limestone is covered by a relatively thick loess layer. Trenches were not buried till 1932, so grazing was impossible there (BML IV/418.b/5).

The stone-quarry has been considerably developed during the 1930's. As a result, the mountain started to disappear fastly (Szita, 2002). Unfortunately, this process is going on, exerting a negative influence on the biota as well as on the microclimatic conditions. From 1936 to 1943, a bauxite mine also operated here (Szita, 2002).

\section{Comparison with two nearby mountains}

In the case on Mt Tubes, considerable erosion has been in progress since the Roman era ( $1^{\text {st }}$ century A.D.), probably indicating deforestation and/or grazing (Erdősi, 1987). Time when grazing stopped could be identified relatively easily and accurately. Southern slopes of the Mecsek Mts near Pécs, including Mt Tubes, were mostly bare, with some scattered, small Quercus individuals in the $18^{\text {th }}$ century, according to the Description of the First Military Survey in 1783-84 (HM Hadtörténeti Intézet és Múzeum Térképtára). This was probably due to sheep grazing. Grazing was abandoned not later than 1890 (Ágh, 1894).

Situation was more problematic in the case of Mt Tenkes. Here, it can be assumed that grazing intensity decreased considerably from the 1940's onwards, and it stopped almost totally during the 1960's (BML XV. 42. Máriagyüd/62.; BML XV. 42. Máriagyüd/91.).

According to the non-supervised classification, shrubforests occupy appr. $85.78 \%$ of the south-facing slope of Mt Tenkes (where grazing was abandoned in the 1960's). In the case of Mt Tubes (where there was no more grazing after 1890), proportion of 
shrubforests is even higher, $96.41 \%$. In this latter case, only small grasslands remained, mainly on the touristically frequented sites.

However, it is important to note that, unlike on Mt Szársomlyó, considerable afforestation with Pinus nigra occurred on Mt Tenkes and Mt Tubes. Thus, our results have to be treated with care.

\section{Discussion}

Our landscape historical analysis has proven that even the most valuable southern slope of Mt Szársomlyó was influenced by humans for millennia. Similar conclusion was drawn by Molnár (1998) in the case of a forest-steppe habitat complex in the Great Hungarian Plain. On Mt Szársomlyó, the shrubforest-rock sward mosaic itself can be considered natural, but the proportion of woody and non-woody vegetation was changed by grazing and other activities (fires, cutting, fire-wood collection). The natural cover percentage of shrubforests and grasslands is unknown, but both components must have been present before human impacts.

Our results contradict the statement of Kelemen (1997), who concluded that grazing cannot be regarded as a traditional land-use technique in the case of rock swards. Historical evidence shows that the southern slope of Mt Szársomlyó was used as a pasture for centuries, maybe for millennia (with some interruptions). According to Kelemen (1997), grazing can spoil rock swards, but this did not happen on Mt Szársomlyó despite considerable grazing pressure.

It is almost certain that different ethnical groups settling down near Mt Szársomlyó utilized the southern slope as a pasture, since lowlands were too wet for this purpose. There is strong evidence that the southern slope was mostly treeless throughout the Middle Ages. Historical data clearly show that the slope was without a considerable forest or woodland cover during the 1800's and the first half of the 1900's, and at the same time, it served as the pasture of the village Nagyharsány. Around 1950, number of grazing animals started to decrease, and grazing virtually came to an end in the 1970's. At the same time, woody vegetation began to expanse. This coincidence cannot be regarded as a sure sign of cause and effect relation (cf. Molnár and Biró, 2010). However, comparison with nearby mountains also showed that the earlier grazing was abandoned, the smaller the area of grasslands is. Since global factors such as $\mathrm{CO}_{2}$ concentration, nitrogen deposition or climatic changes are the same in the three localities, local factors may be regarded as responsible for vegetation alteration. One such local factor is grazing abandonment, although afforestation should also be taken into account in the case of Mt Tenkes and Mt Tubes.

Similar results were published by Molnár (1998) in the Nagykőrös wood, where grazing stopped after the Second World War, and after that, openings began to close. Similar researches are scarce concerning mountain regions in Hungary. Centeri et al. (2009) found that after grazing stopped on the Nyereg Hill, Fraxinus ornus and Cotinus coggygria started to spread rapidly, and within 15 years, almost all slope steppes and rock swards disappeared. The process was accompanied by a reduction in the numbers of protected plants. They concluded that a moderate grazing would be desirable from a conservational point of view.

Borhidi and Sánta (1999) regard cessation of grazing as a considerable threat to the rock sward community Sedo sopianae-Festucetum dalmaticae. However, even if 
grazing is planned to be resumed, careful planning and detailed preliminary surveys are essential (Kiss et al., 2011).

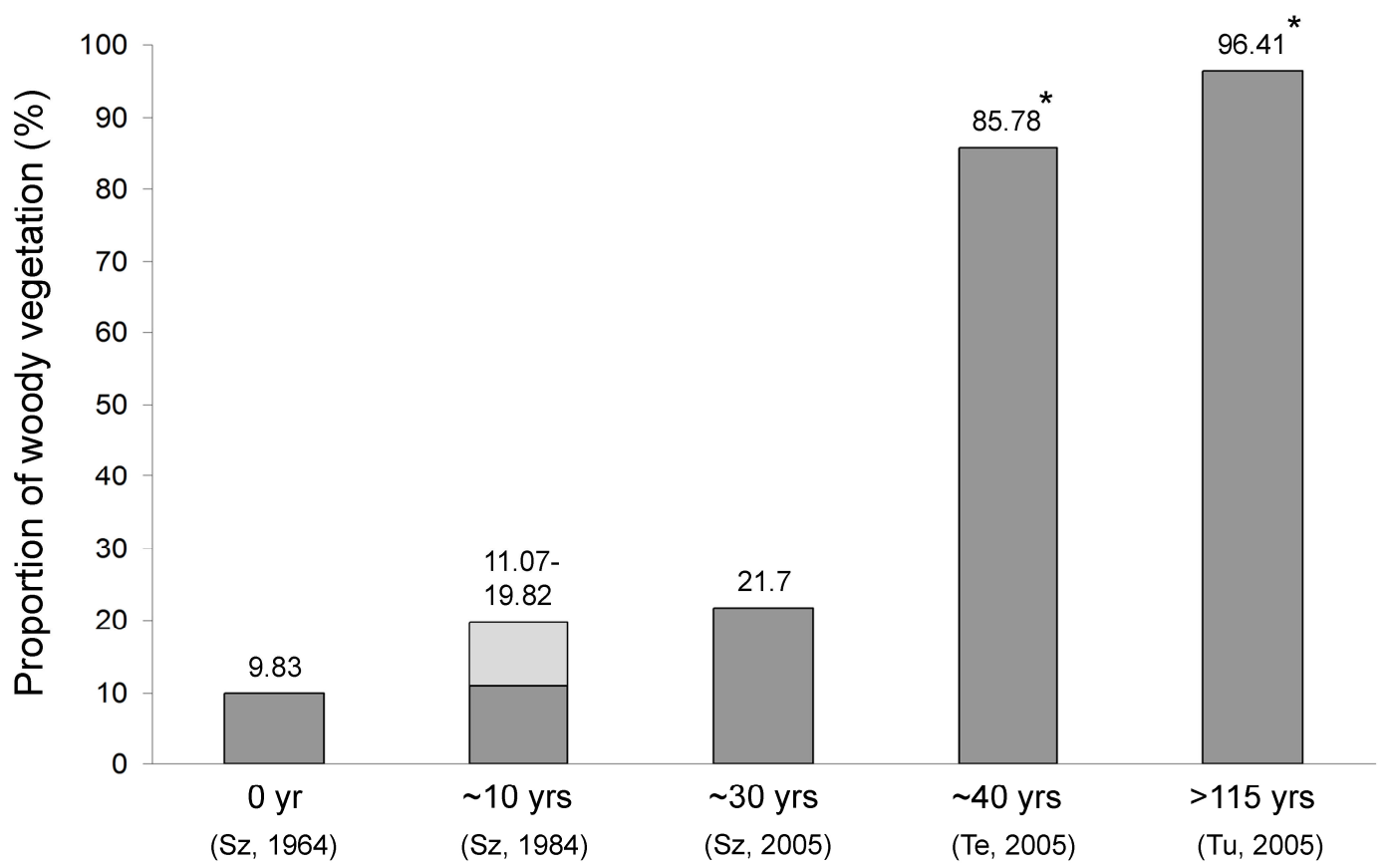

Time since grazing abandonment

Figure 3. Forest area proportions ordered according to time since grazing. Sz: Mt Szársomlyó, Te: Mt Tenkes, Tu: Mt Tubes. Asterisks indicate cover values where afforestation had a considerable influence

Using the data of our analysis, proportion of forested areas can be ordered in a sequence according to time since grazing (Fig. 3). However, as noted earlier, we have to emphasize that factors other than time since grazing may have considerable effects on shrub encroachment. Unfortunately, afforestation (mainly with pine trees) also influenced forest cover increase on Mt Tenkes and Mt Tubes, while this was not the case on Mt Szársomlyó. Moreover, there are slight differences between the three sites regarding geological stratification and steepness of the slopes. Thus, it cannot be concluded that Mt Szársomlyó will reach a forest cover similar to Mt Tenkes or Mt Tubes. Further studies on a finer time-scale as well as monitoring the changes are needed to support nature conservation decisions. This article may serve as a useful starting point.

Acknowledgements. The authors are thankful to Kanász Imre, founder of the Museum of Local History in Nagyharsány for his help in preparing the interviews and collecting some historical data. We also thank Erdős Zoltán and Nagy Imre Gábor, who also provided us with useful historical documents. We are indebted to Tóth Zoltán for his help concerning the aerial photos. The authors are thankful for the following interviewees: Beremendi Ferenc, Kiskovács Pálné Harmat Ilona, Kovács Györgyi, Nagy Ernő, Schlitt Imréné Zajácz Ilona. 


\section{REFERENCES}

[1] Ágh, T. (1894): Emléklapok Pécs sz. kir. város multjából és jelenéből. - Pécs Város, Pécs.

[2] Ambrózy, P., Kozma, F. (1990): Éghajlat: Villányi-hegység. - In: Marosi, S., Somogyi, S. (eds.) Magyarország kistájainak katasztere II, MTA Földrajztudományi Kutató Intézet, Budapest.

[3] Archer, S., Scifres, C., Bassham, C.R., Maggio, R. (1988): Autogenic succession in a subtropical savanna: conversion of grassland to thorn woodland. - Ecological Monographs 58: 111-127.

[4] Archer, S., Schimel, D.S., Holland, E.A. (1995): Mechanisms of shrubland expansion: land use, climate or $\mathrm{CO}_{2}$ ? - Climatic Change 29: 91-99.

[5] Bartosságh, J. (1843): Folytatólagos értesítés a' bálványfa (Ailanthus glandulosa, Götterbaum) terjedése körül. - Magyar Gazda 3: 298-300.

[6] Bond, W.J., Midgley, G.F., Woodward, F.I. (2003): The importance of low athmospheric $\mathrm{CO}_{2}$ and fire in promoting the spread of grasslands and savannas. - Global Change Biology 9: 973-982.

[7] Bond, W.J., Parr, C.L. (2010): Beyond the forest edge: ecology, diversity nd conservation of the grassy biomes. - Biological Conservation 143: 2395-2404.

[8] Borhidi, A., Sánta, A. (eds.) (1999): Vörös könyv Magyarország növénytársulásairól 2. Természetbúvár Alapítvány Kiadó, Budapest.

[9] Bradshaw, R.H.W., Hannon, G.E., Lister, A.M. (2003): A long-term perspective on ungulate-vegetation interactions. - Forest Ecology and Management 181: 267-280.

[10] Briggs, J.M., Knapp, A.K., Blair, J.M., Heisler, J.L., Hoch, G.A., Lett, M.S., McCarron, J.K. (2005): An ecosystem in transition: causes and consequences of the conversion of mesic grassland to shrubland. - Bioscience 55: 243-254.

[11] Brook, B.W., Bowman, D.M.J.S. (2006): Postcards from the past: charting the landscapescale conversion of tropical savanna to closed forest during the $20^{\text {th }}$ century. - Landscape Ecology 21: 1253-1266.

[12] Burkhardt, J.W., Tisdale, E.W. (1976): Causes of Juniper invasion in southwestern Idaho. - Ecology 57: 472-484.

[13] Centeri, Cs., Herczeg, E., Vona, M., Balázs, K., Penksza, K. (2009): The effects of landuse change on plant-soil-erosion relations, Nyereg Hill, Hungary. - Journal of Plant Nutrition and Soil Science 172: 586-592.

[14] Congalton, R., Green, K. (1999): Assessing the Accuracy of Remotely Sensed Data: Principles and Practices. - CRC/Lewis Press, Boca Raton.

[15] Coppin, P., Jonckheere, I., Nackaerts, K., Muys, B., Lambin, B. (2004): Digital change detection methods in ecosystem monitoring: a review. - International Journal of Remote Sensing 25: 1565-1596.

[16] Cremene, C., Groza, G., Rákosy, L., Schileyko, A.A., Baur, A., Erhardt, A., Baur, B. (2005): Alterations of steppe-like grasslands in Eastern Europe: a threat to regional biodiversity hotspots. - Conservation Biology 19: 1606-1618.

[17] Cserhalmi, D., Kristóf, D. (2007): Vegetation change detection on mires with digital aerial photographs. - Cereal Research Communications 35: 329-332.

[18] Dénes, A. (1995): A Mecsek és a Villányi-hegység karsztbokorerdői. - A Janus Pannonius Múzeum Évkönyve 39: 5-31.

[19] Dénes, A. (1998): A Villányi-hegység Chrysopogono-Festucion dalmaticae társulásai. In: Csontos, P. (ed.) Sziklagyepek szünbotanikai kutatása, Scientia Kiadó, Budapest.

[20] Dénes, A. (2000): A Villányi-hegység flóra- és vegetációkutatásának története, eredményeinek összefoglalása, különös tekintettel a védett és ritka fajok előfordulására. Dunántúli Dolgozatok Természettudományi Sorozat 10: 47-77. 
[21] Erdős, L., Gallé, R., Bátori, Z., Papp, M., Körmöczi, L. (2011): Properties of shrubforest edges: a case study from South Hungary. - Central European Journal of Biology 6: 639658.

[22] Erdős, L., Méri, Á., Bátori, Z., Gallé, R., Körmöczi, L. (2012): North-south facing vegetation gradients in the Villány Mountains: a case study on the population and the community level. - Pakistan Journal of Botany 44: 927-932.

[23] Erdős, L., Bátori, Z., Morschhauser, T., Körmöczi, L. (2013): Ecological boundaries at different scales: testing the moving split window analysis using artificial and field data. Polish Journal of Ecology (in press).

[24] Erdősi, F. (1987): A társadalom hatása a felszínre, a vizekre és az éghajlatra a Mecsek tágabb környezetében. - Akadémiai Kiadó, Budapest.

[25] Fodor, I. (1977): Levegő hőmérséklet: Villányi-hegység. - In: Lovász, Gy. (ed.) Baranya megye természeti földrajza, Baranya Megyei Levéltár, Pécs.

[26] Fülep, F., Sz. Burger, A. (1979): Baranya megye a római korban. - In: Bándi, G. (ed.) Baranya megye története az őskortól a honfoglalásig, Baranya Megyei Levéltár, Pécs.

[27] Györffy, Gy. (1987): Az Árpád-kori Magyarország történeti földrajza I. - Akadémiai Kiadó, Budapest.

[28] Haas, M. (ed.) (1845): Baranya. - Lyceumi Könyvkiadó Intézet, Pécs.

[29] HM Hadtörténeti Intézet és Múzeum Térképtára (2004): Az első katonai felmérés. DVD-ROM, Budapest.

[30] Horvát, A.O. (1942): A Mecsekhegység és déli síkjának növényzete. - A Ciszterci Rend kiadása, Pécs.

[31] Horvát, A.O. (1944): A pécsi Mecsek növénytakarójának kettőssége. - A Mecsek Egyesület Évkönyve 53: 3-6.

[32] Kadmon, R., Harari-Kremer, R. (1999): Studying Long-Term Vegetation Dynamics Using Digital Processing of Historical Aerial Photographs. - Remote Sensing of Environment 68: 164-176.

[33] Kelemen, J. (1997): Irányelvek a füves területek természetvédelmi szempontú kezeléséhez. - TermészetBúvár Alapítvány Kiadó, Budapest.

[34] Kiss, L. (1997): Földrajzi nevek etimológiai szótára I-II. - Akadémiai Kiadó, Budapest.

[35] Kiss, T., Lévai, P., Ferencz, Á., Szentes, Sz., Hufnagel, L., Nagy, A., Balogh, Á., Pintér, O., Saláta, D., Házi, J., Tóth, A., Wichmann, B., Penksza, K. (2011): Change of composition and diversity of species and grassland management between different grazing intensity in Pannonian dry and wet grasslands. - Applied Ecology and Environmental Research 9: 197-230.

[36] Knapp, A.K., Briggs, J.M., Collins, S.L., Archer, S.R., Bret-Harte, M.S., Ewers, B.E., Peters, D.C., Young, D.R., Shaver, G.R., Pendall, E., Cleary, M.B. (2008): Shrub encroachment in North American grasslands: shift sin growth form dominance rapidly alters control of ecosystem carbon inputs. - Global Change Biology 14: 615-623.

[37] Köchy, M., Wilson, S.D. (2001): Nitrogen deposition and forest expansion in the northern Great Plains. - Journal of Ecology 89: 807-817.

[38] Lahav-Ginott, S., Kadmon, R., Gersani, M. (2001): Evaluating the viability of Acacia populations in the Negev Desert: a remote sensing approach. - Biological Conservation 98: 127-137.

[39] Lajber, I. (1995): A villányi régió története. - Vintours Kft, Villánykövesd.

[40] Lajber, I. (2000): A villányi borvidék kialakulásának története. - PTE Földrajzi Intézet, Pécs.

[41] Laliberte, A., Rango, A., Havstad, K.M., Paris, J.F., Beck, R.F., McNeely, R., Gonzalez, A.L. (2004): Object-oriented image-analysis for mapping shrub encroachment from 1937 to 2003 in southern New Mexico. - Remote Sensing of Environment 93: 198-210.

[42] Lehmann, A. (1975): A nagyharsányi Szársomlyó-hegy és növényzete. - MTA Dunántúli Tudományos Intézet Közleményei 20: 1-185. 
[43] Lehmann, A. (1979): A Villányi-hegység földrajzi jellemzői. - Földrajzi Közlemények 103: 276-281.

[44] Lovász, Gy. (1977): A természeti adottságok gazdasági értékelése. - In: Lovász, Gy. (ed.) Baranya megye természeti földrajza, Baranya Megyei Levéltár, Pécs.

[45] Marosi, S., Szilárd, J. (1981): A felszín kialakulása. - In: Ádám, L., Marosi, S., Szilárd, J. (eds.) A Dunántúli-dombság (Dél-Dunántúl), Akadémiai Kiadó, Budapest.

[46] Moleele, N.M., Perkins, J.S. (1998): Encroaching woody plant species and boreholes: is cattle density the main driving factor in the Olifants Drift communal grazing lands, southeatern Botswana? - Journal of Arid Environments 40: 245-253.

[47] Molnár, Zs. (1998): Interpreting present vegetation features by landscape historical data: an example from a woodland-grassland mosaic landscape (Nagykőrös wood, Kiskunság, Hungary). - In: Kirby, K.J., Watkins, C. (eds.) The ecological history of European forests, $\mathrm{CAB}$ International, Wallingford.

[48] Molnár, Zs., Biró, M. (2010): A néhány száz évre visszatekintő, botanikai célú történeti tájökológiai kutatások módszertana. - In: Szilassi, P., Henits, L. (eds.) Tájváltozás értékelési módszerei a XXI. Században, JatePress, Szeged.

[49] Molnár, Zs., Bölöni, J., Horváth, F. (2008): Threatening factors encountered: actual endangerment of the Hungarian (semi-)natural habitats. - Acta Botanica Hungarica 50: 199-217.

[50] Ónodi, G., Kertész, M., Botta-Dukát, Z., Altbäcker, V. (2008): Grazing effect on vegetation composition and on the spread of fire on open sand grasslands. - Arid Land Research and Management 22: 273-285.

[51] Pesti, J. (ed.) (1982): Baranya megye földrajzi nevei II. - Baranya Megyei Levéltár, Pécs.

[52] Pesti, J. (szerk.) (2002): Az ördögszántotta hegy. - Alexandra Kiadó, Pécs.

[53] Prins, H.H.T., van der Jeugd, H.P. (1993): Herbivore population crashes and woodland structure in East Africa. - Journal of Ecology 81: 305-314.

[54] Reuter, C. (1976): Baranya megye: Szársomlyó. - In: Kopasz, M. (ed.) Védett természeti értékeink, Mezőgazdasági Kiadó, Budapest.

[55] Roques, K.G., O'Connor, T.G., Watkinson, A.R. (2001): Dynamics of shrub encroachment in an African savanna: relative influences of fire, herbivory, rainfall and density dependence. - Journal of Applied Ecology 38: 268-280.

[56] Roura-Pascual, N., Pons, P., Etienne, M., Lambert, B. (2005): Transformation of a rural landscapein the Eastern Pyrenees between 1953 and 2000. - Mountain Research and Development 25: 252-261.

[57] Sallay, Á., Jombach, S., Filepné Kovács, K. (2012): Landscape changes and function lost landscape values. - Applied Ecology and Environmental Research 10: 157-172.

[58] Sándor, K. (2011): Nyelvrokonság és hunhagyomány. - Typotex, Budapest.

[59] Sărăţeanu, V., Moisuc, A. (2011): Influence of Prunus spinosa L. shrub on the grassland vegetation in western Romania. - Journal of Water and Land Development 15: 65-71.

[60] Schlesinger, W.H., Reynolds, J.F., Cunningham, G.L., Huenneke, L.F., Jarrell, W.M., Virginia, R.A., Withford, W.G. (1990): Biological feedbacks in global desertification. Science 247: 1043-1048.

[61] Silva, J.F., Zambrano, A., Fariñas, M.R. (2001): Increase in the woody component of seasonal savannas under different fire regimes in Calabozo, Venezuela. - Journal of Biogeography 28: 977-983.

[62] Simonkai, L. (1876): Adatok Magyarhon edényes növényeihez. - Mathematikai és Természettudományi Közlemények 11: 157-211.

[63] Somodi, I, Virágh, K, Aszalós, R (2004): The effect of the abandonment of grazing on the mosaic of vegetation patches in a temperate grassland area in Hungary. - Ecological Complexity 1: 177-189.

[64] Stehman, S.V., Czaplewski, R.L. (1998): Design and Analysis for Thematic Map Accuracy Assessment: Fundamental Principles. - Remote Sensing of Environment 64: 331-344. 
[65] Szita, L. (1986): Harkány. - Baranya Megyei Fürdő Vállalat, Harkány.

[66] Szita, L. (2002): Nagyharsány. - Száz Magyar Falu Könyvesháza Kht., Budapest.

[67] van Auken, O.W. (2000): Shrub invasions of North American grasslands. - Annual Review of Ecology and Systematics 31: 197-215.

[68] Várady, F. (ed.) (1896): Baranya multja és jelenje. - Pécsi Irodalmi és Könyvnyomdai Rt., Pécs.

[69] Vargha, K., Rónai, B., Muszty, L. (eds.) (1991): Auf der Spur verborgener Schätze. Tankönyvkiadó, Budapest.

[70] Wigley, B.J., Bond, W.J., Hoffman, M.T. (2010): Thicket expansion in a South African savanna under divergent land use: local vs. global drivers? - Global Change Biology 16: 964-976.

[71] Zólyomi, B. (2007): Magyarország természetes növénytakarója. - In: Járainé Komlódi, M. (ed.) Magyarország növényvilága, harmadik kiadás, Urbis Könyvkiadó, Budapest.

\section{MAPS}

[72] Map of all shared pastures of Nagyharsány in Baranya County, 1844. - Baranya County Archives BML XV. 3. BIU 568.

[73] Map of the vineyard of Nagyharsány according to the arrangement of 1862. - Baranya County Archives BML XV. 3. BIU 569.

[74] Map of Nagyharsány according to the arrangement of 1864. - Baranya County Archives BML XV. 3. BIU 570/b.

\section{ARCHIVE DOCUMENTS}

[75] Minutes of the meeting of the Nagyharsány Mountain Grazing Association, 1930. Documents of the Administrative Board of Baranya County IV-3-1945, Nagyharsány. Baranya County Archives BML IV/418.b/1.

[76] Minutes of the Meeting of the Nagyharsány Mountain Grazing Association, $8^{\text {th }}$ July 1933. Documents of the Administrative Board of Baranya County IV-3-1945, Nagyharsány. Baranya County Archives BML IV/418.b/2.

[77] Account of the Nagyharsány Mountain Grazing Association, 1935. Documents of the Administrative Board of Baranya County IV-3-1945, Nagyharsány. - Baranya County Archives BML IV/418.b/3.

[78] Account of the Nagyharsány Mountain Grazing Association, 1933. Documents of the Administrative Board of Baranya County IV-3-1945, Nagyharsány. - Baranya County Archives BML IV/418.b/4.

[79] Minutes of the Meeting of the Nagyharsány Mountain Grazing Association, $2^{\text {nd }}$ April 1932. Documents of the Administrative Board of Baranya County IV-3-1945, Nagyharsány. - Baranya County Archives BML IV/418.b/5.

[80] Postcard No 62 from the postcard collection of Károly Borsy. - Baranya County Archives BML XV. 42. Máriagyüd/62.

[81] Postcard No 91 from the postcard collection of Károly Borsy. - Baranya County Archives BML XV. 42. Máriagyüd/91. 